\title{
Using Nature in Architecture: A perspective from Antoni Gaudi
}

\author{
Şeyda Emekci ${ }^{*}$ \\ $\mathbf{1}^{*}$ Ankara Yıldırım Beyazıt University, Architecture and Fine Arts Faculty, Departmant of Architecture, Ankara, Turkey, (ORCID: 0000-0002-5470-6485), \\ semekci@ybu.edu.tr
}

(2nd International Conference on Applied Engineering and Natural Sciences ICAENS 2022, March 10-13, 2022)

(DOI: $10.31590 /$ josat.1073073)

ATIF/REFERENCE: Emekci, Ş. (2022). Using Nature in Architecture: A perspective from Antoni Gaudi. European Journal of Science and Technology, (34), 87-91.

\begin{abstract}
Beginning in the early 1990s, environmental concerns began to take a more prominent position on the world agenda. The necessity for establishing a relationship between architecture and nature has become apparent as a result of increased public awareness of the repercussions of uncontrolled urban expansion and climate change. The consequences of reforms aimed at integrating environmentally friendly solutions into the construction of buildings have altered public perceptions of the modern built environment. Although this relationship is perceived as new, it is rooted in ancient times. Over the course of history, many architects have recognized the need of developing a link with the environment and have taken steps to achieve this relationship. Antoni Gaudi is one of the architects who made a significant contribution to this collaboration. The aim of this article is to rediscover the relationship between nature and architecture through the works of Antoni Gaudi.
\end{abstract}

Keywords: Sustainable architecture, Energy efficiency, Biomimicry, Antoni Gaudi.

\section{Doğayı Mimarlıkta Kullanmak: Antoni Gaudi'den Bir Perspektif}

Öz

1990'ların başlarından itibaren çevresel kaygılar dünya gündeminde daha fazla yer almaya başladı. Kontrolsüz kentsel genişleme ve iklim değişikliğinin yansımaları konusunda artan kamuoyu bilincinin bir sonucu olarak, mimarlık ve çevre arasında ilişki kurmanın gerekliliği ortaya çıkmıştır. Çevre dostu çözümleri binaların inşasına entegre etmeyi amaçlayan reformların sonuçları, modern yapılı çevreye ilişkin kamu algısını değiştirmiştir. Bu ilişki yeni gibi algılansa da kökleri çok eskilere dayanmaktadır. Tarih boyunca birçok mimar, çevre ile bir bağ geliştirmenin gerekliliğini fark etmiş ve bu ilişkiyi gerçekleştirmek için adımlar atmıştır. Antoni Gaudi, bu iş birliğine önemli katkı sağlayan mimarlardan biridir. Bu makalenin amacı çevre ve mimarlık ilişkisini Antoni Gaudi'nin eserleri üzerinden yeniden keşfetmektir.

Anahtar Kelimeler: Sürdürülebilir mimari, Enerji verimliliği, Biyomimikri, Antoni Gaudi.

\footnotetext{
*Corresponding Author: semekci@,ybu.edu.tr
} 


\section{Introduction}

As people grow more cognizant of the environmental impact of human activities, legislative constraints on architectural and urban design are becoming tighter. Building materials and construction procedures that are more ecologically friendly are being developed by architects in response to this trend. Inspirations from nature can be seen when they are used to improve energy efficiency, air quality control, water and sewage management systems, among other things. The features obtained from the environment can be included in the design of buildings, their surroundings, and their interiors. Therefore, it has been inevitable that nature and architecture establish a relationship. Despite the fact that this connection is viewed as new, it has roots that go back thousands of years. Throughout history, many architects have understood the need of building a connection with the surrounding environment and have taken measures to accomplish architecture this connection. For example, "Seven lamps of," according to Ruskin, can be used to promote growth and progress by taking into consideration the harmonic order seen in nature [1]. William Morris advocates for the restoration of open space in the countryside, as well as for the self-sufficiency of local industry [2]. The goal of this relationship is to minimize the negative impact on the environment caused by energy consumption and any other usage of natural resources [3].

Nature has always served as a key inspiration for many designs, and it continues to play a vital part in architectural design. The notion has been refined by a number of different architects throughout the years, and it continues to gain attention due to its relevance. Antonio Gaudi (1852-1926), the most prominent architect in Catalonia, is internationally renowned for his inventiveness, which he derived from nature's mimicry, among other sources of inspiration. Many of his structural and aesthetic breakthroughs were the result of his in-depth research of nature. Specifically, the purpose of analyzing Antoni Gaudi who demonstrate a significant difference in their work based on climatic and regional characteristics is to demonstrate that they were influenced by the environments in which he grew up and designed buildings and objects that reflected his own local tradition. He believed that nature and the surrounding environment had an inextricable relationship with architecture and that it was preferable to imitate the formal expression of current organic architecture in buildings rather than contemporary architecture [4]. This essay seeks to rediscover the link between nature and architecture by examining the works of Antoni Gaudi.

\section{Nature as a Source of Inspiration}

The architecture draws inspiration from a diverse variety of sources in order to overcome challenging design obstacles and challenges. Nature is being studied, and researchers are striving to understand the ways in which it has evolved to cope with environmental issues as one option for solving the problem. In architecture, nature's inspiration serves as a driving force, inspiring the building of spectacular structures and monuments across the world.

Natural science and architecture are now being combined in order to establish a total synergy between the building and the surrounding environment, much as organic architecture started to emulate components from nature and the natural environment decades ago [5]. 'Biomimicry' is the term used to describe this form of philosophy, which comes from two Greek words: 'Bios', which means life, and 'Mimesis,' which means imitation. It is a strategy of looking at natural phenomena seen in nature and using them to assist in the progress of humans that has been around for quite some time [6].

When it comes to construction activities and the built environment, sustainable development is often referred to as sustainable building or sustainable structure. The construction sector is one of the largest social and economic sectors in Europe and the world, and the built environment has a significant impact on the natural environment. The building sector and the built environment are presented as the two key areas in the development of global sustainable development, and they are also the most important in the development of global sustainable development.

Designers must take into account structural efficiency, water efficiency, zero-waste systems, thermal environment, and energy supply while creating a sustainable design in architecture. It is a new way of perceiving and valuing nature that is based not on what we can take from nature, but on what we can learn from it. Biomimicry is a new way of viewing and valuing nature that has emerged as an alternative approach [7].

\section{Gaudi and His Works: Harmony and Unity Inspired by Nature}

Catalan architect Antonio Gaudi, who is the architect of seven works that have been designated as UNESCO World Heritage Sites, is often considered to be the greatest architect of twentiethcentury architecture [8]. He has been praised for his artistic and creative ability, as well as the innovation of his naturalistic architectural style with its surprising shapes and colors. He has also been hailed for his interesting technical and constructive innovations, as well as the hygienic and bioclimatic qualities of his architecture, but his contribution to architectural history has received little attention as a pioneer in the disciplines of sustainability and biomimetics in modern architecture [9]. Construction practices have been more wasteful and aggressive with environmental resources from the mid-nineteenth century; sirens sounded around the end of the twentieth century in industrialized civilizations. However, many of the ideas that are now being researched in the subject of sustainability in architecture are already considered important by Gaudi, who lived a century before them and put them into effect in his works [10]. Gaudi was enhancing the energy efficiency of his buildings via the use of classic bioclimatic tactics as well as creating novel technology. At times, he developed new and unusual shapes utilizing old materials and processes [11]. With the use of passive mechanical air conditioning systems at Casa Batlló, Gaudi was able to maximize the usage of renewable energy. The Casa Batlló incorporates all of the benefits of solar energy, including thermal gains from direct solar radiation, diffused sunshine, and Aeolian energy, and does so in a comfortable and energy-efficient manner since there is no asymmetrical ventilation [12]. 


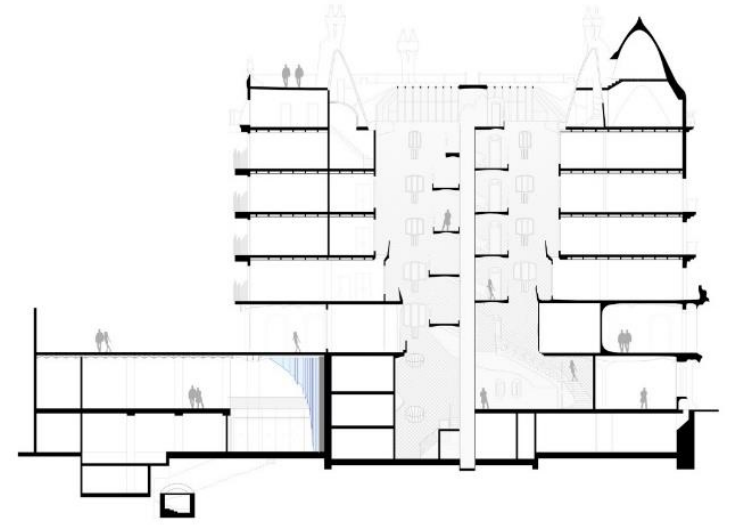

Fig. 1 Casa Batlló- Longitudinal section [13]

The center courtyard serves not only as a thermic regulator but also as a well for the surrounding buildings. As one looks along the longitudinal section of the structure, it becomes apparent that one of the façades has been relocated in both inner courtyards in order to increase the surface area of the zenithal skylight. With the help of the diaphragmatic functioning of the courtyard's hole, as well as the contribution of hot air, it is feasible to achieve temperatures of $+2 / 3 \mathrm{oC}$ at the lowest point of the courtyard. The quantity of light that enters the courtyard rises with the amount of light that leaves the courtyard [12].

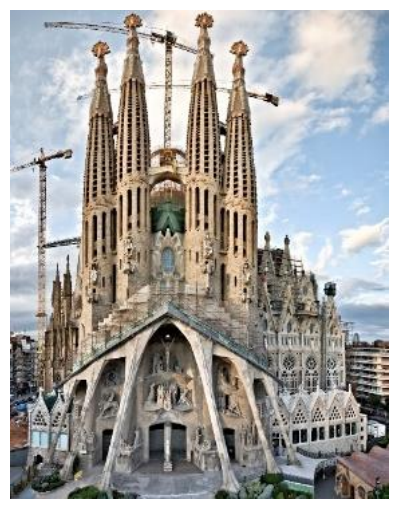

Fig. 2 La Sagrada Familia (Source: Author)

Gaudi's other prominent work The Sagrada Familia's original aerodynamic design, which includes a parabolic vertical section as well as a circular horizontal section, reduces wind force by more than half, which is one of the main problems associated with high-rise constructions. This is in comparison to the steeples, which were designed with a continuous square horizontal section as was done in the original project; the openings in the surface of the bell towers designed by Gaudi also contribute to this reduction in wind force. It is able to do so while conserving a significant amount of resources [9].

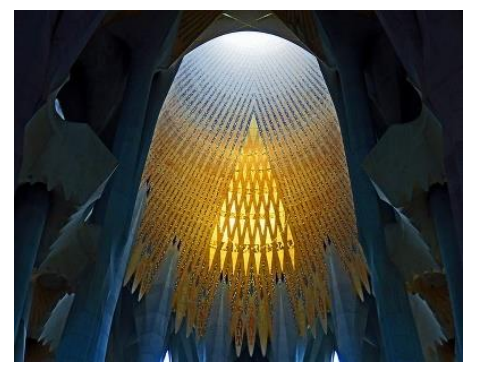

Fig. 3 La Sagrada Familia (Source: Author)
In an effort to exceed and improve upon the Gothic, Gaudi built the vaults of the Sagrada Familia, which are formed by hyperboloids and can be seen throughout the structure. These ruled surfaces have an important hole in the center for overhead lighting, which was reached by the old Gothic vaults, which are placed in the middle of the governed surfaces. The ancient Gothic vaults are positioned in the middle of the governed surfaces. A significant amount of natural light can be brought into the buildings as a consequence of this. Similarly, Large patios of lights were also constructed at Casa Mila by Gaudi to improve lighting and ventilation on all levels, and the windows on the lower stories were also increased to compensate for the lack of sunlight.

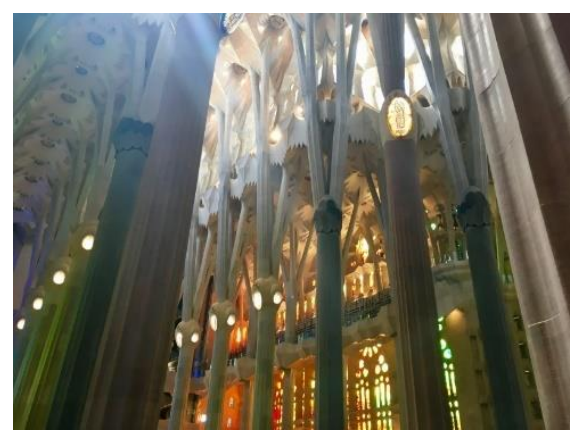

Fig. 4 La Sagrada Familia (Source: Author)

Furthermore, exterior moats were a common feature in Gaudi's designs for both the Casa Botines and the Episcopal Palace of Astorga. Casa Botines' skylights and patios stretch up to the roof, ensuring that no corners of the structure are obstructed by darkness, and allowing for more natural light to reach the bottom level. To accomplish thermal insulation in his structures, Gaudi investigates the best methods of doing so, particularly in the sections most exposed to cold and heat, such as roofs and walls. That is why he commonly said that the cover had to be "hat and umbrella," referring to the fact that it had to be double-sided [14]. Besides, Windows on the north façade of El Capricho de Comillas, a Cantabrian town distant from the mild Mediterranean climate, feature double glazing to better insulate the rooms' temperature from the outside elements. Considering the time period, this is a noteworthy development. 


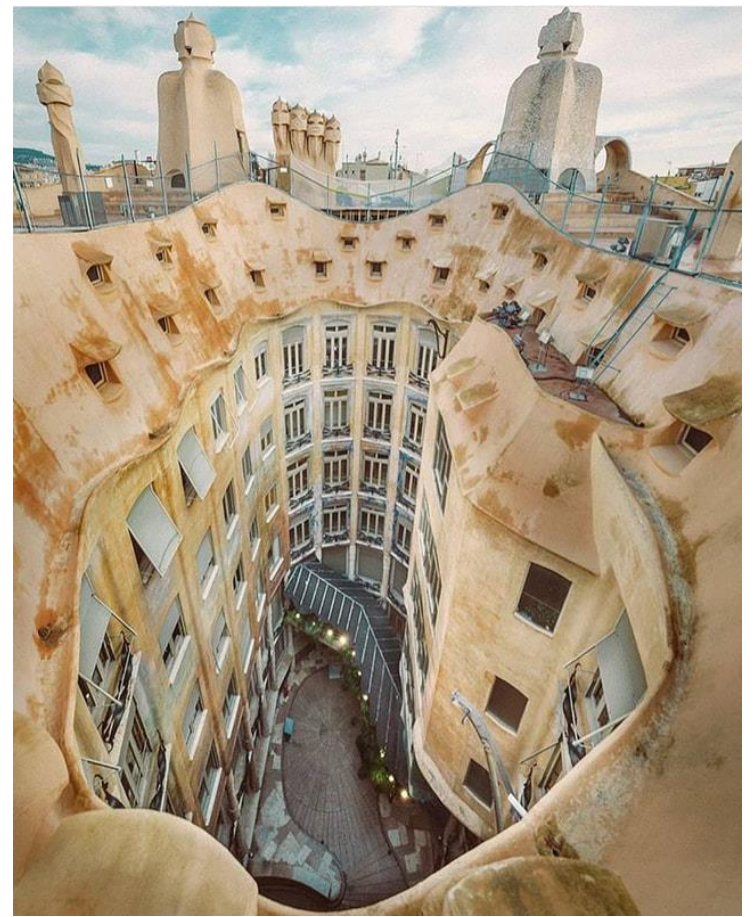

Fig. 5 Casa Milá [15]

El Capricho is a U-shaped home with a greenhouse on the southern side, designed by Antoni Gaudi in the early 20th century. By using the limited amount of sunlight available in this northern Spanish town, and introducing it into the residence, it is able to absorb thermal energy generated via the greenhouse effect. The main goal of the house's design is to maximize the amount of solar energy that can be harvested via the greenhouse, which is why each room is structured in the most efficient manner possible.

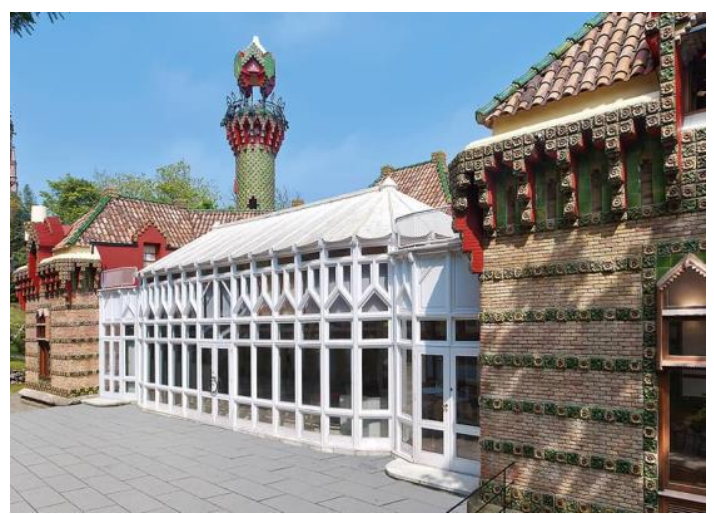

Fig. 6 El Capricho (Source: Author)

At the time, Gaudi was a trailblazer in the reuse and recycling of building waste from scrap or demolition, which was misunderstood and even ridiculed by several. An old Catalan term for using shattered pieces of glass or tile to cover things like chimneys or facades, "trencadís" means "broken" in Catalan [9].
The Park Güell, Casa Batlló, Casa Milá, and Temple of Sagrada Familia are examples of Gaudi's usage of this approach.
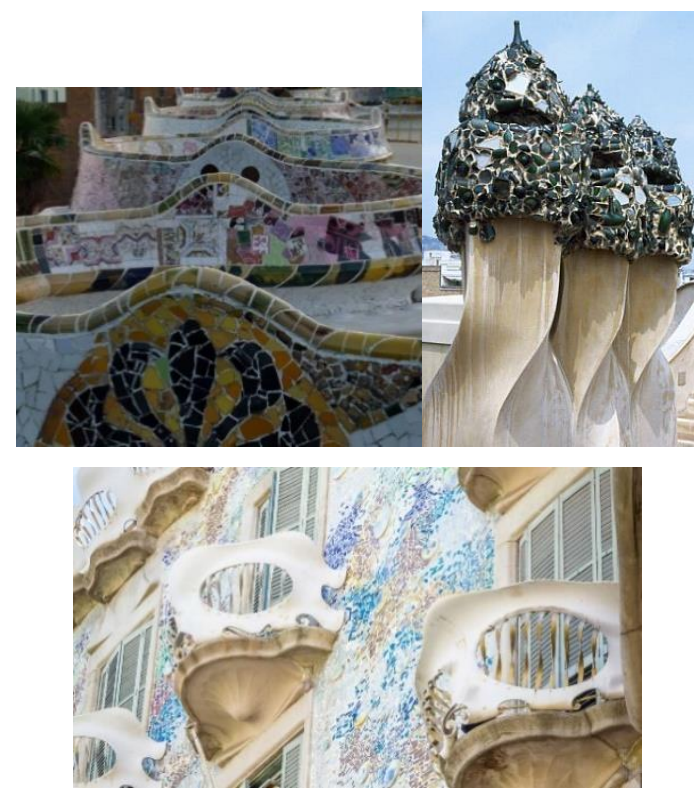

Fig. 6 Trencadís (Source: Author)

\section{Conclusion}

Humanity is being confronted with rising problems from climate change, as well as experiencing the consequences of climate change. Rising temperatures, heat waves, severe precipitation events, floods, and droughts are creating economic losses and social instability, as well as harming human health and well-being.

Throughout history, architects have turned to nature for inspiration. Nature-based solutions were effective in addressing social difficulties resulting from climate change in a long-term manner. Antoni Gaudi was one of them. Antoni Gaudi was influenced by nature and he was able to translate concepts from nature, such as those found in the hyperboloids and paraboloids, into his architecture.

Gaudi's works followed local tradition, namely Catalan Gothic, and stressed harmony and coherence between the structure and the surrounding environment, which was influenced by nature. And he represented organic architecture by using wood, bones, muscle-tendon, and other organic materials to make organic creations appear. Furthermore, stone has an almost limitless ability to be shaped into the shapes that Gaudi desired. It has readily unperceived continuous curves to create his architecture, which he can easily create. The example of Gaudi tells us that the sustainability of architecture is intricately linked to a variety of other values, including aesthetic, scientific, and technical values, and these days when climate change is being recognized as a significant issue, it is critical for the architecture of the $21 \mathrm{st}$ century to be ecologically friendly to be successful. 


\section{References}

[1] Ruskin, J. (1849). The seven lamps of architecture. New York, NY, USA: J. Wiley.

[2] Miller, E. (2011). Sustainable Socialism: William Morris on Waste. The Journal of Modern Craft, 4, 7-25. https://doi.org/10.2752/174967811X12949160068974

[3] Emekci, S. (2021). Nature-centered design: a comparative analysis in current architectural approaches. Presented at the LIVENARCH VII livable environments \& architecture, Trabzon, Turkey.

[4] Kim soyeon \& Yoon Jae Eun. (2015). A Study on Organic Architecture Characteristics in Works of Gaudi and Hundertwasser. 한국공간디자인학회 논문집, 10(6), 2332.

[5] Mumford, M. (1989). Form Follows Nature: The Origins of American Organic Architecture. Journal of Architectural Education, 42(3), 26-37. https://doi.org/10.1080/10464883.1989.10758528

[6] Pawlyn, M. (2019). Biomimicry in architecture. Routledge.

[7] Amer, N. (2019). Biomimetic Approach in Architectural Education: Case study of 'Biomimicry in Architecture' Course. Ain Shams Engineering Journal, 10(3), 499-506. https://doi.org/10.1016/j.asej.2018.11.005

[8] González Moreno-Navarro, A. (1990). Gaudí, constructor (la materialización de una arquitectura singular). González Moreno-Navarro, 42(408), 5-8. https://doi.org/10.3989/ic.1990.v42.i408.1423

[9] Mirat, C., Bedoya, C., \& Adell, J. (2018). Antonio gaudí, the forerunner of sustainability and biomimicry in architecture, 100 years in advance. Architecture, City and Environment, 12, 71-98. https://doi.org/10.5821/ace.13.37.5348

[10]Pantano, M. (2013). Reading Gaudi' Reading Gaudi's Great Book of Nature Reconsidering the Peripher peripheral Reception of al Reception of Proto-Environmental Architecture. The University of Pennsylvania.

[11] Nonell, J. (2012). La construcción tradicional en la arquitectura de Gaudí. Informes de La Construcción, 42, 9 14. https://doi.org/10.3989/ic.1990.v42.i408.1424

[12] Guardiola Usón, E., \& Cunill de la Puente, E. (2005). Passive solar design in Antonio Gaudi's domestic architecture (p. 4). Presented at the International Conference "Passive and Low Energy Cooling for the Built Environment," Santorini, Greece.

[13]ArchDaily. (2021). Gallery of New Interior for Casa Batlló Stairs \& Atrium / Kengo Kuma \& Associates - 14. Retrieved January 17, 2022, from https://www.archdaily.com/967908/new-interior-for-casabatllo-stairs-and-atrium-kengo-kuma-andassociates/613141b825f70e016663f5bc-new-interior-forcasa-batllo-stairs-and-atrium-kengo-kuma-and-associatessection

[14]Bassegoda, J. (1989). El gran Gaudí. Ausa: Sabadell.

[15]EMARQ. (2021). Casa Milà (La Pedrera) obra de Antoni Gaudí - EMARQ. Retrieved January 17, 2022, from https://www.emarq.net/blog/casa-mila-la-pedrera 